\title{
THE INTERNATIONAL COMMISSION FOR PLANT RAW MATERIALS
}

by

C. RegeL

New Members of the Commission:

Dr. Roland Runkel, Reinbek bei Hamburg.

Dr. Wifredo de Ráfols, Madrid.

As the Committee in Geneva, Switzerland could not assume the costs for the planned first meeting of the Commission in Geneva, this meeting has been postponed.

1953, August 17-21-the General Meeting of the International Union of Biological Sciences will take place in Nice, France. As the International Commission for Plant Raw Materials belongs to this Union, it is planned to invite the members of the International Commission for Plant Raw Materials to the meeting in Nice in order to discuss some problems connected with the Commission as e.g. programm of the work of the Commission, budget of the Commission, foundation of an International Association for Plant Raw Materials comprising all countries, cooperation with other existing Societies and Associations working in the sphere of Plant Raw Materials.

\section{International Botanical Congress in Paris}

The 8th International Congress of Botany will be held in Paris from Friday the 2nd to Wednesday the 14th of July 1954. The provisinal and detailed programm of the Congress will be sent to all Botanists, Agronomists, Foresters ete, whose addresses are known to the Secretariat of the Congress, 292 Rue Saint Martin-Paris (3-e) France. President of the Congress is Roger Heim, General Secretary Pierre Chouard and Assistant Secretary Roger de Vilmorin.

The Congress will include among other sections a Section for Plant Raw Materials. All informations about this Section may be obtained from Professor R. Paris, 4 Avenue de l'Observatoire, Paris (6-me). France. 